\title{
Leadership and Ethnicity in Public Companies in Malaysia
}

\author{
Dominic Lai Yew Hock
}

\begin{abstract}
Corporate Governance gained prominence in Malaysia during the Asian financial crisis of 1997, which operated as a wake up call that the existing corporate governance structures in public listed companies were insufficient. In response, Kuala Lumpur Stock Exchange issued the Listing Requirements on 22 January 2001 to regain investors' confidence and attract foreign direct investments. The Listing Requirements included a Code of Best Practices in Corporate Governance that favours the leadership structure of separate Chairman/Chief Executive Officer posts. Malaysia is a multi-racial country comprising predominantly of the indigenous Malays, the Chinese and the Indians. The Chinese in Malaysia continue to play a significant role in the economy. These Chinese practise a distinctive Chinese business culture in the running of their businesses. The literature reveals that the adoption of the prescribed leadership structure of separating the Chairman and Chief Executive Officer positions is not likely to improve the financial performance of Chinese controlled companies. An empirical research is conducted, using 218 Chinese controlled public listed companies in Malaysia. The data covered three years from 2001 to 2003. Financial performances of the companies were measured using return on equity, earnings per share, dividend per share, liquid asset per share and gross margin. t-test and Mann Whitney test were used. The results show that there has been widespread adoption of the leadership structure recommended under the Code by the sample companies. The results also show that adoption of the prescribed leadership structure under the Code has no significant impact on the financial performance of the sample companies.
\end{abstract}

\section{Keywords}

Corporate governance, separate chairman/CEO posts, Chinese business culture.

\section{Development of Corporate Governance in Malaysia}

There were already some measures of corporate governance in Malaysia before the 1997 Asian crisis. Malaysia Securities Commission is the securities regulatory body established under the Securities Commission Act 1983, with investigative and enforcement powers. In 1995, the Securities Commission started the disclosure based regime (DBR) of the primary markets. The implementation of DBR was premised on the high corporate governance standards practised by public listed companies. In 1996, the Registry of Companies, the body in charge of the administration of the Companies Act 1965, developed a Code of Ethics for directors (Kadir, 1999).

The Asian economic crisis began with the plunge of Thai baht on 2 July 1997, and rapidly swept through other neighbouring countries, including Malaysia (Kotler \& Kartajaya, 2000). Foreign direct investments in Malaysia dropped from USD5.1 billion in 1997, to USD3.7 billion in 1998 (Haley, 2000). Weak corporate governance was cited as the major cause of the Asian crisis (Mitton, 2002). As a result, Malaysia saw the need to improve corporate governance in companies to regain investors' confidence.

The Finance Committee on Corporate Governance was set up in 1998 to review and reform the standards of corporate governance (Kang, 2001). The Finance Committee defines corporate governance as "the process and structure used to direct and manage the business affairs of the company towards 
enhancing business prosperity and corporate accountability with the ultimate objective of realising long-term shareholder value, while taking into account the interest of other stakeholders" (Abdullah, 2004, p. 49) [emphasis added]. The mandate given to the Finance Committee was wide, which covered (Kadir, 1999):

- A code of best practices in corporate governance. The Malaysian Code on Corporate Governance is conceived. The Code sets out broad principles of good corporate governance, and best practices for companies. Companies are required to disclose in their annual reports a narrative statement of how they apply the relevant principles, and the extent to which they have complied with the best practices (Kang, 2001).

- A review of the legal infrastructure, and enforcement mechanisms. Enforcement has always been a weakness. In the Corporate Governance Watch-Corporate Governance in Asia published in April 2003, Malaysia scores the highest (9 out of 10) in legal infrastructure, compared to Singapore (8.5) and Hong Kong (8.0). However, Malaysia is weak in enforcement, scoring only 3.5, compared to Singapore (7.5) and Hong Kong (6.5) (Osman, 2004).

- A training and education programme for directors. Kuala Lumpur Stock Exchange has taken steps to educate all directors of public listed companies, as they are required to attend a mandatory induction programme (MAP). The Exchange then introduced a Continuing Education Programme (CEP) on 1 July 2003, which requires directors of public listed companies to attend a minimum number of training programmes each year, in order to maintain their directorship (KLSE Practice Note No. 15/2002).

In March 1998, the Malaysian Institute of Corporate Governance (MICG) was established, who was charged with promoting public awareness of corporate governance practices (Haat \& Mahenthiran, 2003). A Minority Shareholder Watchdog Committee (MSWG) was also set up to fight abuses against minority shareholders. MSWG became a platform for initiating shareholder activism against questionable conduct by the management of public listed companies. MSWG could represent the minority shareholders to vote on their behalf in general meetings (Kadir, 1999). In year 2000, the Taskforce on Internal Controls was established by Kuala Lumpur Stock Exchange. The Taskforce was responsible for the formulation of guidance to assist public listed companies to report the state of their internal control in the annual reports.

On 22 January 2001, Kuala Lumpur Stock Exchange introduced the Listing Requirements which included a Code on Corporate Governance. The Listing Requirements are modelled after the AngloSaxon model, more particularly the UK Codes comprising of the Cadbury, Greenbury and Hampel Reports (Kang, 2001). The government has taken proactive steps in encouraging compliance with corporate governance. In 2003, Public Bank and IJM Corporation, public companies in Malaysia, were named as the joint winners of the prestigious Malaysian Business Corporate Governance Award (Low, Yong \& Shanmugam, 2004). The Malaysian government hopes that improvements to corporate governance will boost the confidence of foreign investors. This will position the nation with a competitive advantage globally in order to attract foreign direct investments, and to attain developed nation status (Chan, 2003).

In January 2004, the powers of Malaysia Securities Commission are enlarged, following amendments to the Securities Commission Act 1993. With the increased powers, Securities Commission now has the power to take pre-emptive actions (even before the commission of the offence) against any director who is found likely to contravene any securities law. The errant director may be removed from office, or barred from becoming a director of any public listed company. Provisions are also made in the amended Securities Industry 1983 for whistle blowing, and the protection of whistle blowers. Enforcement systems are now being used. 


\section{Chinese Business Culture}

Malaysia former Prime Minister, Tun Dr Mahathir Mohamad, acknowledged in his speech at the $7^{\text {th }}$ World Chinese Entrepreneurs Conference held in Kuala Lumpur on 28 July 2003, that the Chinese constitute the third largest economy in the world, after USA and Japan, and the estimated wealth has reached USD1.5 trillion (The Borneo Post, 29 July 2003, p. 1). The acknowledgement is warranted. The fast food chain, Kenny Rogers' Roasters of USA, is now owned by Vincent Tan of Malaysia. The fashion house, Laura Ashley of UK, is now owned by Khoo Kay Peng of Malaysia (Backman, 2001). The top ten Chinese owned companies in Malaysia control 28.3 percent of total market capitalisation (Khan, 2003, p. 14).

The Chinese have a distinctive culture in running their businesses. They operate their enterprises as family companies (Backman \& Butler, 2003). The company is synonymous with family. The family is synonymous with the recognition of the anointed leader as the patriarch (Yeung \& Soh, 2000). The family members have a strong sense of hierarchical power. They accept decisions handed down, and are cautious about how they present their own ideas upward (Crookes \& Thomas, 1998). They know their places in the company, and hardly challenge formal authority. Decision making rights are not normally disputed $(\mathrm{Yu}, 2001)$. In return, the family members are well looked after, and generously compensated for their undivided loyalty and trust (Haley \& Tan, 1999).

The Chinese way of doing business is different from westerners. The Chinese believe that one builds guanxi (relationship) first, and the contracts will follow, whereas the westerners build transactions, and if they are successful, a relationship will follow (Hutchings \& Murray, 2002). While the western concept of networking depends on legal contracts, the Chinese businessmen use guanxi for reciprocity, and perceive the relationship as a means to an end (Li \& Wright, 2000). It is, thus, quite common for Chinese business leaders to undertake projects to support government policy, regardless of the profits. In return, the government rewards them by giving favourable concessions (Haniffa \& Cooke, 2002). This symbiotic relationship between the Chinese leaders and the government works well.

\section{Practice of Leadership Structure in Companies}

\section{Support for separate titles}

The chairman is normally a part timer, and his role is to monitor and evaluate the performance of management, including the Chief Executive Officer $(\boldsymbol{C E} \boldsymbol{O})$. The chairman should be distanced from daily operations of the company, in order to stay objective when making strategic policy decisions (Roberts, 2002). On the other hand, the CEO is a full time post, and he is responsible for the daily operations in the company. The chairman runs the board, and the CEO runs the company. Leading the board and leading the company are two distinct jobs (Gunther, 2002).

The most important role of the board is to appoint, monitor, mentor and replace (if necessary) the CEO (Nicholson \& Kiel, 2004). It will be difficult for the board to efficiently carry out that role if the chairman of the board is also the CEO. The separation of the two roles will ensure effective checks and balances over the management's performance (Haniffa \& Cooke, 2002). No one single person should possess unbridled power in the company. When companies perform poorly, stockholders often push for the separation of the chairperson and the CEO positions as a means to restore the company's credibility with investors (Sundaramurthy, Mahoney \& Mahoney, 1997).

Should a chairman of the board occupy an executive or non-executive position? The possible chairmanship options in situations of separate chairman/CEO roles are shown in Figure 1. 


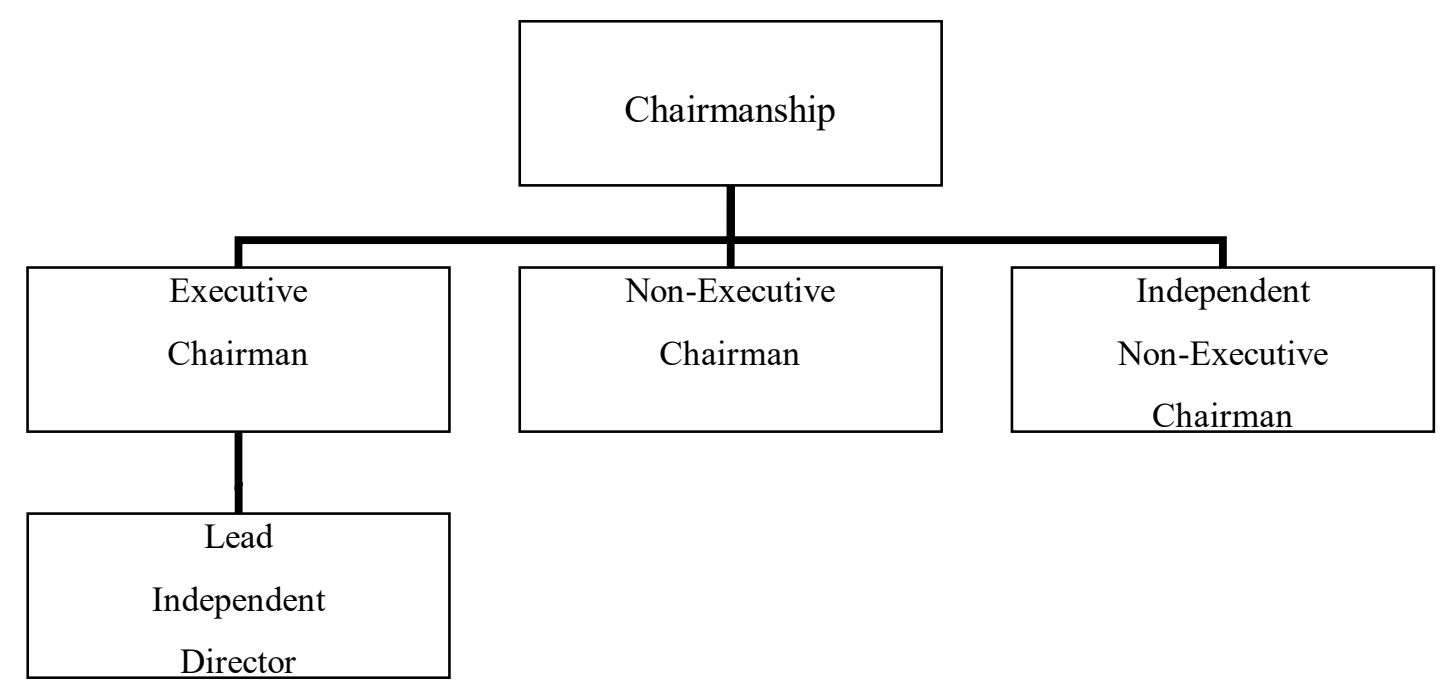

Figure 1 Possible chairmanship options in situations of separate chairman/CEO roles

Separate titles will become meaningless if the chairman occupies an executive position. It has been proposed that the board should be led by a non-executive chairman (Keenan, 2004). In Malaysia, a study of 92 companies listed on the main board of Kuala Lumpur Stock Exchange shows that only 23 percent of these companies have non-executive chairmen (Low, Yong \& Shanmugam, 2004).

Another suggestion goes further- that the board should be led by an independent non-executive chairman (Zong, 2004). The rationale is that the independent board chair will be in a better position to ensure proper and timely disclosure of information, set sensible agenda, and encourage candid discussion in the boardroom. What if the company appoints an executive chairman nevertheless? In that case, a lead independent director should be named, whose task is to work with the executive chairman to set the agenda for the meetings, and to liaise between the board and management. The lead independent director can be the bridge between the management and outside directors (Dalton \& Dalton, 2005).

Is the suggestion of appointing an independent non-executive chairman acceptable to Chinese controlled companies? Not likely. It is inconceivable that the chairman, being the leader of the top echelon of the Chinese enterprise, is not the founder/patriarch of the company. What then is the efficient matrix between chairman and founding shareholder in Chinese controlled companies? The possible matrix is shown in Figure 2.

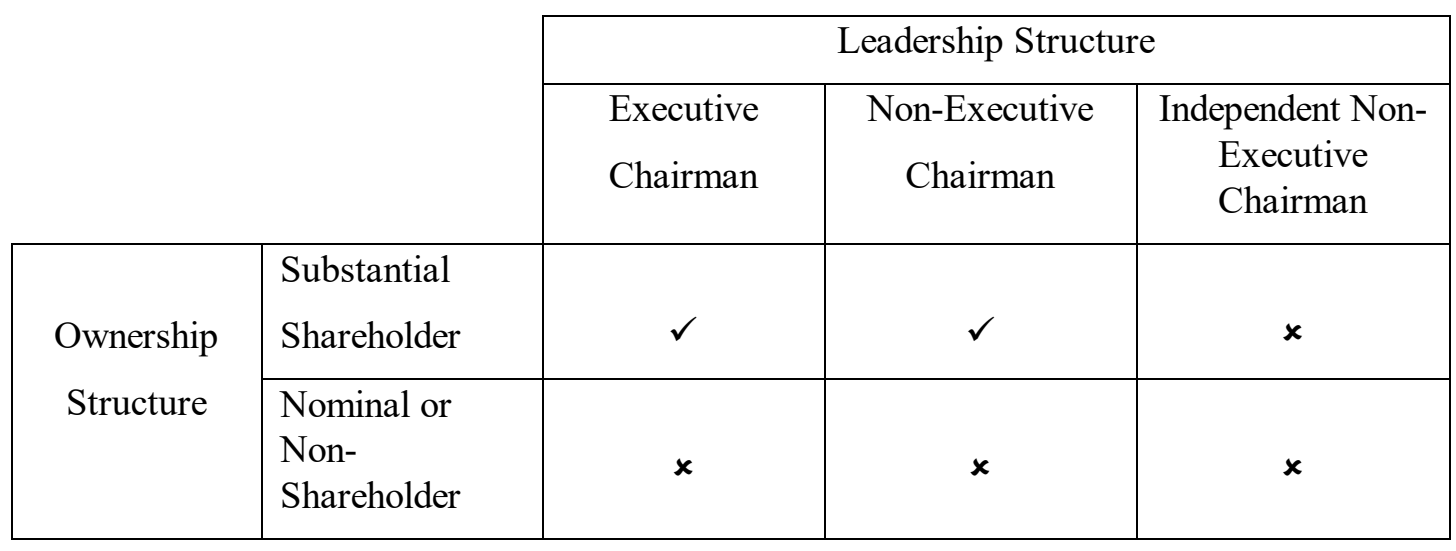

Figure 2 Matrix of leadership structure and ownership structure in Chinese controlled companies 
The boxes marked " $\sqrt{ }$ " mean that option is perhaps acceptable in Chinese business settings. In the context of separating the positions of the chairman and the CEO, it exposes the range of possibilities on the relationship between leadership structure and ownership structure in Chinese controlled companies:

- Executive chairman. He will inevitably be the founder and substantial shareholder. The chairman is involved in operational matters of the company, albeit on a part time basis. $\mathrm{He}$ becomes the founder/owner/manager/chair. The board chairman is unlikely to monitor the activities of the management in an independent and objective matter. In fact, there is no need at all for the chairman to monitor the affairs of management, because he is the management.

- Non-executive chairman. The chairman leads the board and makes policy decision. He confines himself to managing the board rather than the company. His influence on the managers depends on whether the chairman is a substantial shareholder of the company. If he were, it matters not whether he holds the executive or non-executive chair, because he will have absolute influence over the CEO. If he were not, he is likely to be the nominee of the substantial Chinese owner, and is not in a position to influence the management anyway.

- Independent non-executive chairman. This option will not materialise in a Chinese controlled company. It is unlikely to happen in a family company, because the founder needs to maintain control over the family members.

\section{Support for combined titles}

For Chinese businesses, unitary leadership structure is often indispensable. The owner of a public listed company is often the founder. He is akin to the brand name of the company. While the corporate sector in the west is a community of companies, the business community in Asia is a community of personalities (Backman, 2004). The emphasis is different. When China Cyberport in Hong Kong bought a stake in Kerry Group, the big news was that Indonesian tycoon Oei Hong Leong had bought a stake in the company owned by Malaysian tycoon Robert Kuok (Backman \& Butler, 2003). Robert Kuok is nicknamed the 'sugar king of Malaysia' because he produces the sugar needs of the country, and owns 30 percent of Sucden Kerry International, the world's largest sugar trader (Yueng \& Soh, 2000). Yet people hardly know the name of his company that produces the sugar.

It is thus inconceivable in the filial minds of family members, workers, suppliers and customers that the founder does not occupy the top positions in the board and management. Lim Goh Tong, founder of Malaysia sole casino operator, Genting Berhad, recently announced his decision to step down as CEO after 34 years at the helm, to be replaced by his son (The Borneo Post, 28 Nov 2002, p. 1). He remains as chairman. He steps down for one reason only: he was 85 years old.

One of the strengths of Chinese businesses is the speed of decision making that is centralised in the leader (Li, Khatri \& Lam, 1999; Haley 1997). Missing an opportunity is worse than losing family fortune, because it means losing face, and losing the guanxi (relationship) (Yu, 2001). The founder often unilaterally makes business decisions, and seeks board endorsements subsequently (Yueng \& Soh, 2000). A unitary leadership structure becomes important in maintaining this decision making process to sustain competitive advantage in the Asian and global markets, because it offers a clear mandate to a single leader to react faster to external events (Fan, Lau \& Wu, 2002).

The founders of Chinese listed companies often have little formal education (Kim, Kandemir \& Cavusgil, 2004; Haley \& Tan, 1999). Their decision making process is thus different from western models. They draw from their experiences, advice from trusted friends developed through xinyong (trust), and their intuitive perception of the situations (Haley, 1997). Board deliberations before decisions are an archive concept to them. They assume positions of chairman and CEO to preserve the powers to decide within the corporate structure.

Is the perceived goodness of separate titles, therefore, a myth? Companies like Enron, World-com, Vivendi and Deutsche Telecom practise the separate titles, and yet the scandals could not be avoided 
(Sonnenfeld, 2004). On the other hand, Parmalat Finanziara SpA of Italy that practised a combined chairman/CEO role, filed for bankruptcy protection in late December 2003, and was regarded as the biggest corporate collapse in Europe (Buchanan \& Yang, 2005). Theoretically, it is not possible to determine which leadership structure is best. The optimal leadership structure varies according to the economic circumstances facing the company, and there is no formula of universal application.

\section{Practices in Leadership Structure and its Likely Impact on Financial Performance of Chinese Controlled Public Listed Companies in Malaysia}

Part AA II of the Malaysia Code of Best Practices in Corporate Governance states that there should be a clear division of responsibilities between the chairman and CEO. This will ensure a balance of power and authority, such that no one individual has unfettered powers of decision. The Malaysia Finance Committee on Corporate Governance that formulated the Code acknowledges that enhancing shareholder value is the long term overall objective of the company (Ow-Yong \& Cheah, 2000). The issue is whether this leads the prescribed leadership structure under the Code to be a better monitor and, thus, is capable of enhancing shareholder value.

The Code supports and prescribes separate titles. The link of separate titles to financial performance of companies produces mixed results. Some authors find that separation of board chair and CEO has no significant impact on financial performance of companies (Daily et al., 2002; Fan, Lau \& Wu, 2002; Elloumi \& Gueyie, 2001; Weir \& Laing, 2001; Daily \& Dalton, 1997). However, Brickley, Coles \& Jarrell (1997) find that companies with separate titles consistently outperform companies with combined titles. Then Simpson and Gleason (1999) find that the combined titles may positively influence the internal control system of a banking company, and improve financial performance. Overall, there is no compelling empirical support for the view that separate titles have a positive impact on financial performance of companies.

In Chinese controlled companies, the ownership structure is concentrated (Low, Yong \& Shanmugam, 2004). The Chinese (typically family oriented) controls more than half of the public listed companies in Malaysia (Low, 2003). In Chinese family owned companies, family members usually control the board and management. These family companies inherently have a more complex structure than non-family companies. The Chinese patriarch has to balance the interplay between family traditions and family business culture, continuing employment for filial relatives (regardless of their competency), against the need to engage professional managers, which ultimately affect the goals, strategies, structure and performance of the family company. Direction of the company is often determined more by emotion, than by principles of sound governance.

The entwined relationship among family members, and between family members and non-family members, may cover the whole spectrum of stewardship at one end, and agency theory at the other end (Steier, Chrisman \& Chua, 2004). The accountability aspect of corporate governance may not be all important, when the owners are also managers of the company. Minority interests are often ignored. The business prosperity aspect of corporate governance is fulfilled as long as the company thrives. The substantial shareholders in the company are the family members, and they are unlikely to expect higher dividends, as long as the founder is the chair of the board. In fact, most of the profits will be retained for investment purposes.

In such situation, there is really no division between owner/board/management, and accountability through separation of chairman/CEO positions becomes insignificant. In the circumstances, the Code that recommends separate chairman/CEO titles is perhaps misguided. Splitting the titles will diffuse leadership, and confuse the workers as to who is in command (Allan \& Widman, 2000). Dual leadership structure makes it difficult to pinpoint the blame for bad corporate performance. Moreover, the person holding the combined titles would be driven by the desire to do well, because he is ultimately responsible 
(Weir, 1997). A strong unitary leadership structure can send signals to the market that the company has a clear sense of direction (Finkelstein \& D'Aveni, 1994).

\section{Research}

Abdullah (2004) perceives that a company that adopts the prescribed leadership structure will enjoy improved monitoring ability and accountability, which will then lead to improved financial performance. This is possible because management abuses will be curtailed. It means that a company that splits the positions of chairman and CEO will enjoy improved financial performance. There is thus a perceived association between leadership structure and financial performance of a company. Because of the high economic influence of Chinese in Malaysia (Ward, Pearson \& Entrekin, 2002), it becomes necessary and interesting to test the said perceived association in one demographic condition - the Chinese business cultural environment. An empirical study is conducted.

\section{Variables}

The independent variable is the separate titles. The dependent variable is the financial performance of Chinese controlled public listed companies in Malaysia that is measured by return on equity (ROE), earnings per share (EPS), dividend per share (DPS), liquid asset/share (LAS) and gross margin (GM). ROE is a measure of net profit relative to ordinary shareholder's investment in a company, and is measured by dividing net profit after tax by total ordinary shareholders equity. EPS is a measure of the earnings performance of each ordinary share during a fiscal period, and is computed by dividing net profit after tax by the ordinary shares outstanding. DPS is measured by dividing dividends after tax by the ordinary shares outstanding. LAS is measured by dividing liquid assets (total current assets minus stocks-in-trade) by the ordinary shares outstanding. GM is a percentage measured by dividing gross profit over sales. Gross profit is measured by sales less cost of goods sold.

\section{Hypothesis}

The literature and theoretical arguments are that the prescribed leadership structure in separating the positions of the chairman and the CEO is not receptive to the Chinese entrepreneurs, who may adopt the same in form but not in substance. The adoption of the prescribed leadership structure is, therefore, unlikely to have an impact on the financial performance of Chinese controlled public listed companies in Malaysia. Hence, the hypothesis is that separation of chairman and CEO positions is not likely to improve the financial performance of Chinese controlled public listed companies in Malaysia.

\section{Determinants of Chinese controlled public listed companies}

There are a few indicators whether a public listed company in Malaysia is controlled by Chinese. The shareholdings are the clearest indicators. Chinese control is manifested when they are the single biggest shareholder or major shareholder in the company. In line with the New Economic Policy in Malaysia that was introduced in 1971, the bumiputra (indigenous people of Malaysia) usually holds 30 percent equity in public listed companies (Backman, 2001). However, their shareholdings are usually diluted over time through disposal and various exercises (Haniffa \& Cooke 2002; Yeung 1999). The Chinese entrepreneurs effectively need only 15 percent equity to reach the critical level of control in a public listed company (Yeh, Lee \& Woidtke, 2001). They are also able to control the company through the management as the CEO or Managing Director. At the board level, the Chinese entrepreneurs usually control the company by occupying the executive chair, or by letting a bumiputra occupy the nonexecutive chair. In Malaysia corporate scene, it is not unusual for a bumiputra to hold the non-executive chair. The purpose is to add value to the company, and in compliance with the spirit of New Economic Policy. In the selection criteria for Chinese controlled public listed companies, these companies possess all the three determinants.

\section{Sample selection criteria}

Public companies in Malaysia are listed variously on the main board, the second board and MESDAQ. In order to ensure that the sample size in terms of paid up capital is fairly consistent, only companies 
listed on the main board of Kuala Lumpur Stock Exchange are considered. There are public listed companies that are classified as PN4 (Practice Note No. 4) companies. These PN4 companies seek protection of the court from creditors while going through the corporate restructure. The financial performance of PN4 companies will be subject to many extraneous factors while undergoing the restructure, and will not accurately establish a leadership structure/financial performance relationship. These PN4 companies are, therefore, excluded for the purpose of this research. Financial and insurance companies are excluded because they are separately regulated.

The Code of Best Practices in Corporate Governance were issued on 22 January 2001. In testing the leadership structure/financial performance relationship, it will be meaningful to assess the impact of leadership structure prescription on financial performance after the introduction of the Code. The effectiveness of the Code recommendations on leadership structure should be discernable using the three years' data. The time span represents almost three full years from 2001 to 2003, during which public listed companies have the opportunity to comply with the Code. Most companies would have or should have complied with the Code by then. Moreover, these years are considered relatively stable after the Asian financial crisis, so that distortion of data is minimised.

The sample taken is, therefore, in respect of those companies that have complete financial data for the years 2001, 2002 and 2003. The research focuses on matured companies to ensure that financial data is stable. Arbitrarily, public listed companies that are established at least five years before 2001 are considered mature. That means companies which are listed on and before 1996 will be included in the sample.

After going through the sample selection criteria, and the application of the determinants of Chinese controlled public listed companies, the sample consists of 218 Chinese controlled public companies listed on the main board of Kuala Lumpur Stock Exchange for the three years 2001, 2002 and 2003. These sample companies cover all sectors of the industry, except the financial and insurance companies which are separately regulated.

\section{Descriptive statistics}

Table 1 shows the descriptive statistics that is used to gain an understanding of the characteristics of the sample for the three years 2001, 2002 and 2003. The incidence of duality (Chairman and CEO combined posts) was not high in 2001 with only 11 percent of the Chinese controlled public listed companies having the same person holding the posts of chairman and CEO. It shows that these companies have adopted the separate-titles leadership structure prescribed in the Code. There is clear evidence of a move away from duality, with only less than 10 percent of the companies exhibiting combined titles in the years 2002 and 2003. Overall, the financial measures indicate that the Chinese controlled public listed companies that configure their leadership structure in accordance to the Code appear to perform better financially.

Table 1 Descriptive statistics

\begin{tabular}{lccccccccc}
\hline & & 2001 & & & 2002 & & \multicolumn{2}{c}{2003} \\
& Minimum & Maximum & Mean & Minimum & Maximum & Mean & Minimum & Maximum & Mean \\
\hline Duality & 0 & 1 & 0.11 & 0 & 1 & 0.09 & 0 & 1 & 0.09 \\
ROE (\%) & -447.36 & 65.74 & -6.4581 & -487.42 & 42.19 & -2.3041 & -544.16 & 319.99 & 2.5120 \\
EPS & -272.00 & 238.00 & 2.9903 & -273.00 & 566.00 & 9.3406 & -47.20 & 782.00 & 16.1450 \\
DPS & 0 & 101.00 & 5.3101 & 0 & 171.00 & 5.2555 & 0 & 115.00 & 5.5000 \\
LAS & 0 & 44.56 & 0.7178 & 0 & 49.89 & 0.7646 & 0 & 55.52 & 0.8087 \\
GM (\%) & -75.55 & 100.00 & 28.3051 & -18.49 & 100.00 & 29.2276 & -114.72 & 100.00 & 29.5435 \\
\hline
\end{tabular}




\section{Board characteristics}

Table 2 shows the frequency of occurrence of the board characteristics. Since the introduction of the Listing Requirements in January 2001, there is a steady decrease in duality leadership structure to only 9 percent in 2003. The adoption of separate-titles leadership structure has increased to 90.83 percent by 2003.

Table 2 Board characteristics - frequency table

\begin{tabular}{lccc}
\hline Board characteristics & 2001 & 2002 & 2003 \\
& $\mathrm{n}(\%)$ & $\mathrm{n}(\%)$ & $\mathrm{n}(\%)$ \\
\hline Duality & $23(10.55)$ & $20(9.17)$ & $20(9.17)$ \\
Separate titles & $195(89.45)$ & $198(90.83)$ & $198(90.83)$
\end{tabular}

\section{t-test}

Table 3 shows the results of the t-test. Throughout the three years 2001 to 2003, there is no significant difference in the association between the separation of chairman/CEO posts and the five financial measures (ROE, EPS, DPS, LAS and GM) in Chinese controlled public listed companies in Malaysia. Therefore, the hypothesis is supported when using all the five financial measures for the three years 2001 to 2003 .

Table 3 Results from t-test

\begin{tabular}{lcccccc}
\hline & \multicolumn{3}{c}{ Mean differences } & \multicolumn{3}{c}{ t-values } \\
Test variable & 2001 & 2002 & 2003 & 2001 & 2002 & 2003 \\
\hline Separate titles & & & & & & \\
ROE (\%) & 9.07433 & -3.18451 & -5.32561 & 0.704 & -0.334 & -0.479 \\
EPS & -0.34906 & -6.57670 & -11.28530 & -0.036 & -0.505 & -0.753 \\
DPS & -1.31880 & -1.75116 & -0.48444 & -0.496 & -0.512 & -0.918 \\
LAS & -0.28500 & -0.33485 & -0.50175 & -0.405 & -0.400 & -0.539 \\
GM (\%) & 0.26278 & 0.11794 & -0.53452 & 0.061 & -0.026 & -0.103
\end{tabular}




\section{Mann Whitney test}

Table 4 shows the results of the Mann Whitney test. Throughout the three years 2001 to 2003, there is no significant difference in the association between the separation of chairman/CEO posts and the five financial measures (ROE, EPS, DPS, LAS and GM) in Chinese controlled public listed companies in Malaysia. Therefore, the hypothesis is further supported when using all the five financial measures for the three years 2001 to 2003 .

Table 4 Results from Mann Whitney test

Comparison of ROE and board characteristics for years 2001 to 2003

\begin{tabular}{llllllllll}
\hline & 2001 & ROE & Z value & 2002 & ROE & Z value & 2003 & ROE & Z value \\
\hline Duality & $\mathrm{N}=22$ & 106.39 & & $\mathrm{n}=19$ & 102.39 & & $\mathrm{n}=20$ & 86.43 & \\
Separate titles & $\mathrm{N}=$ & 106.51 & -0.009 & $\mathrm{n}=193$ & 106.90 & -0.306 & $\mathrm{n}=198$ & 111.83 & -1.717 \\
& 190 & & & & & & & &
\end{tabular}

Comparison of EPS and board characteristics for years 2001 to 2003

\begin{tabular}{llllllllll}
\hline & 2001 & EPS & Z value & 2002 & EPS & Z value & 2003 & EPS & $Z$ value \\
\hline Duality & $\mathrm{N}=23$ & 112.48 & & $\mathrm{n}=20$ & 102.48 & & $\mathrm{n}=20$ & 90.43 & \\
Separate titles & $\mathrm{N}=$ & 108.59 & -0.281 & $\mathrm{n}=197$ & 109.66 & -0.488 & $\mathrm{n}=198$ & 111.43 & -1.419 \\
& 194 & & & & & & & &
\end{tabular}

Comparison of DPS and board characteristics for years 2001 to 2003

\begin{tabular}{llllllllll}
\hline & 2001 & DPS & $\mathrm{Z}$ value & 2002 & DPS & $\mathrm{Z}$ value & 2003 & DPS & $\mathrm{Z}$ value \\
\hline Duality & $\mathrm{N}=23$ & 108.85 & & $\mathrm{n}=20$ & 108.28 & & $\mathrm{n}=20$ & 92.18 & \\
Separate titles & $\mathrm{N}=$ & 109.58 & -0.053 & $\mathrm{n}=198$ & 109.62 & -0.093 & $\mathrm{n}=198$ & 111.25 & -1.314 \\
& 195 & & & & & & & &
\end{tabular}

Comparison of LAS and board characteristics for years 2001 to 2003

\begin{tabular}{llllllllll}
\hline & 2001 & LAS & Z value & 2002 & LAS & Z value & 2003 & LAS & Z value \\
\hline Duality & $\mathrm{N}=23$ & 109.76 & & $\mathrm{n}=20$ & 111.60 & & $\mathrm{n}=20$ & 104.30 & \\
Separate titles & $\mathrm{N}=$ & 108.91 & -0.061 & $\mathrm{n}=198$ & 109.29 & -0.156 & $\mathrm{n}=198$ & 110.03 & -0.387 \\
& 194 & & & & & & & &
\end{tabular}

Comparison of GM and board characteristics for years 2001 to 2003

\begin{tabular}{llllllllll}
\hline & 2001 & GM & $\mathrm{Z}$ value & 2002 & $\mathrm{GM}$ & $\mathrm{Z}$ value & 2003 & $\mathrm{GM}$ & $\mathrm{Z}$ value \\
\hline Duality & $\mathrm{N}=23$ & 119.37 & & $\mathrm{n}=19$ & 115.97 & & $\mathrm{n}=19$ & 111.92 & \\
Separate titles & $\mathrm{N}=$ & 107.77 & -0.838 & $\mathrm{n}=198$ & 108.33 & -0.507 & $\mathrm{n}=198$ & 108.72 & -0.212 \\
& 194 & & & & & & & &
\end{tabular}




\section{Summary of Results}

The results show that there has been widespread adoption of the leadership structure recommended under the Code of Best Practices in Corporate Governance by Chinese controlled public listed companies. Most of these companies have adopted the separate-titles leadership structure prescribed in the Code. Malaysia has indeed improved in the governance practice of moving away from duality.

The relationship between this recommended leadership structure and financial performance was then analysed to assess whether or not the adoption of this leadership structure was associated with improved financial performance of the sample companies. The results of the study find no association between separate-titles leadership structure and financial performance of Chinese controlled public listed companies in Malaysia. The findings are not unexpected. Empirical studies have found that generally separation of board chair and CEO has no significant impact on financial performance of companies (Daily et al., 2002; Fan, Lau \& Wu, 2002; Elloumi \& Gueyie, 2001; Weir \& Laing, 2001; Daily \& Dalton, 1997).

In line with the Chinese business culture, the Chinese entrepreneurs of these companies will run the companies in their own distinctive monopolistic nature. These Chinese businessmen started off by holding the combined posts of board chairman and CEO to ensure business efficacy. When the Listing Requirements were introduced in 2001, the study finds that most of these companies began separating the positions of chairman and CEO. The Chinese entrepreneurs themselves tend to hold the board chair. The CEO positions are delegated to their trusted people. The Chinese business culture of operating on a 'need to know' basis continues to persist, and the CEO knows well enough not to step out of line. The CEO carries out his tasks with the tacit blessing of the chairman. The unwritten rule is that the CEO will act within his confines, and will not act in ways that may invite the wrath of the chairman. Hence, the type of leadership structure, whether separate or combined titles, has no significant effect on how the Chinese controlled public listed companies perform financially.

The Code highlights two aspects of corporate governance - accountability and business prosperity. From the findings, the prescribed leadership structure in the Code is likely to play a significant role in the accountability aspect of corporate governance, rather than the business prosperity aspect. Can better accountability in the company, then, lead to wealth creation? In improving accountability, the directors will examine risk management and control. In enhancing business prosperity, the directors will need to focus on direction and strategy. Perhaps the more appropriate link is that improved accountability in the company will prevent wealth reduction through abuses by management.

\section{Limitations}

The study has some limitations. The study encompasses data of Chinese controlled public listed companies in Malaysia only. The results of the study should not be generalised across nationalboundaries, because of demographic and environmental differences (Soederberg, 2003). Good governance is an adaptive process that caters to the specific circumstances of each country (Lu \& Batten, 2001), and cannot fit into established templates (Letza, Sun \& Kirkbride, 2004). Moreover, the effectiveness of boards of directors cannot be determined solely by leadership structure (Roberts, 2002). Generally, empirical research appears to examine governance variables in a univariate context. When the leadership structure is studied in an isolated context for causal effect, the findings have a confounding effect, and are usually not generalisable (Coles, McWilliams \& Sen, 2001). 
Interviews or case studies are not deployed to examine in depth a few companies to obtain an insight into decision making process in the choice of leadership structure. The research can perhaps be more meaningful by complementing it with an ethnographic study on the directors. However, there will be the inevitable problem of access and whether board members are willing to cooperate. Chinese controlled public listed companies in Malaysia do not readily welcome interviews or studies into the boardroom affairs. It is surmised that the effectiveness of boards cannot be determined by mere board configuration, and the results of any quantitative study are bound to be equivocal.

The perennial question is whether there is indeed a link between corporate governance and financial performance of companies. Corporate governance is founded on accountability. Local and foreign fund managers are willing to pay at least 10 percent premiums on Malaysia public listed companies that have excellent corporate governance practices (KLSE-PricewaterhouseCoopers, 2002). It is, therefore, assumed that a company that practises corporate governance standards will enjoy improved financial performance. Is the assumption correct? Is it possible that a company with high corporate governance standards may, nevertheless, not perform well financially because of market forces? A pharmaceutical company with admirable corporate governance practices may not do well financially because there is no world epidemic. A rubber manufacturing company with hardly any corporate governance practices may do extremely well financially because of the sudden surge in demand for plastic containers due to Lal Nina floods.

The link between corporate governance and financial performance of companies is built on a broad base of assumptions. If the assumptions are unfounded, the link collapses. The search for the link can be like the search for the 'Holy Grail' (Bradley, 2004, p. 8). Can the search be in the wrong place? The general understanding is that adherence to the Code of Best Practices in Corporate Governance will improve accountability in the company. Hence, the direct causal effect to Code compliance should be the matter of accountability, not the matter of financial performance. Accountable governance ensures public confidence in the company, and this enhances the value of the company. If financial performance of the company improves as a result of adoption of the Code, that should be incidental. The probable causal link is shown in Figure 3.

\begin{tabular}{|l|l|l|}
\hline Code & $\Rightarrow \quad$ Better \\
Compliance & accountability
\end{tabular}$\quad \Rightarrow \quad \begin{aligned} & \text { Improved } \\
& \text { financial } \\
& \text { performance }\end{aligned}$

Figure 3 The link between corporate governance and financial performance of companies

Malaysia Listing Requirements, or the UK Cadbury Report, are probably not asserting a bold statement that adoption of their recommendations will improve financial performance of companies. Some researchers have indeed questioned whether there is any correlation between board governance and financial performance of companies (Kakabadse, Kakabadse \& Kouzmin 2001). 


\section{Further Research}

This paper presents opportunities for integrative research into areas of Chinese business culture, and corporate governance. The challenge is to take the current framework and operationalise the variables. An issue is whether the observed outcome in this study is applicable generally to Malaysian business culture, and not necessarily limited to Chinese business culture only as advanced in this study. It is entirely possible that the lack of relationship between the Code on leadership structure and financial performance established in this study may not be unique only to Chinese controlled public listed companies in Malaysia. Such lack of relationship may be common among other ethnic (Malay, Indian) controlled public listed companies in Malaysia as well. The absence of such relationship may even be prevalent among government linked or foreign owned public listed companies in Malaysia. If that were the case, then the extension of this study will be that the Malaysian business culture in general is not receptive to the recommended leadership structure prescribed under the Code, and that compliance with the Code does not contribute to the financial performance of the companies.

In emerging markets like Malaysia, the founders of most public listed companies are aging. Their siblings trained in western values are taking over (Backman \& Butler, 2003). As the second generation of Chinese business leaders is equipped with western values, a transformation is taking place (Li, Khatri \& Lam, 1999). Xinyong (trust) is losing ground, and replaced by systems trust whereby one's word is no longer good enough, and the negotiating party needs to examine the paid up capital of the company (Tong \& Yong, 1998). This new generation of Chinese leaders of listed companies in Malaysia is driven by shareholders' value creation and high accountability to the stakeholders within the companies. These western values could co-exist with the traditional value of family wealth creation of the second generation of Chinese business leaders who are also the major shareholders. The Malaysian Code of Corporate Governance could, thus, be more receptive to this new generation of corporate players.

\section{Conclusion}

The Code of Best Practices in Corporate Governance prescribes a leadership structure that favours the separation of chairman/CEO posts. The results of the empirical study are that the prescribed leadership structure under the Code has no significant impact on the financial performance of Chinese controlled public listed companies in Malaysia. Even though there has been widespread adoption of the leadership structure recommended under the Code by Chinese controlled public listed companies as shown in the study, it suggests a mere symbolic move in governance compliance by these companies, rather than a substantive move to improve financial performance.

It is acknowledged that good corporate governance practices are essential to protect shareholders, and to instil investors' confidence. However, from the results of the empirical study in this paper, the Code on leadership structure is not likely to be successfully assimilated into the Chinese business culture. Most Chinese controlled public listed companies in Malaysia are not characterised by widely dispersed ownership under the agency theory framework, but by family control. These companies evolve from traditional family owned enterprises, and they do not see the need to embrace more openness in business practices. Khan $(1998,2003)$ argues that family-based corporate governance system is in itself a distinctive type of corporate governance.

However, the route to corporate governance is, perhaps, inevitable. Following the Asian crisis, CalPERS draws up a set of global governance principles to ensure that the funds it commits to Asia are not invested in companies that lack corporate governance. CalPERS requests that its profile of invested companies be composed of predominantly Independent Non-Executive Directors, and it publicly names companies that exhibit poor corporate governance practices. CalPERS, in fact, pulled out investments in Malaysia, Indonesia, Thailand, and Philippines in February 2002, citing concerns over corporate governance.

Malaysia has moved in the direction of improving corporate governance by introducing the Listing Requirements in 2001. The subsequent 10-year Malaysia Capital Market Master Plan is placing heavy 
emphasis on corporate governance reforms. The Master Plan is a blueprint for action in the Malaysian capital market. In the light of recent failure to protect the interest of minority shareholders in troubled companies such as Malaysia Airlines and Renong, there is doubt whether governance practices will be effectively implemented in Malaysia. Should governance practices be intensified? Datuk Dr Shafie Mohd Salleh (2004), Deputy Finance Minister of Malaysia, feels that a market that is too governed is inherently better than a market that lacks corporate governance. Failure in corporate governance will weaken a company's defences to scandals, suspension in trading, and a possible collapse of the company. The Malaysian government recognises the challenge on governance enforcement and announced on 15 May 2004, the creation of a new Corporate Governance Committee (headed by the chairman of the Securities Commission) that reports directly to the Prime Minister.

As long as the managers are in charge of public funds, there is the need for corporate governance to mitigate manager-shareholder conflict. However, there is no universal prescription applicable to all economies. It is one thing to blame the Asian crisis on lack of good governance, and quite another to impose the western model of corporate governance that runs against the Chinese business culture. Asian values are still important as they stress the importance of harmony, while the western values place heavy emphasis on freedom and individualism. What Asia needs is perhaps a hybrid: the best of East and West.

\section{References}

Abdullah, SN 2004, 'Board composition, CEO duality and performance among Malaysian listed companies', Corporate Governance, vol. 4, no. 4, pp. 47-61.

Allan, P \& Widman, A 2000, 'A Comparison of the Views of CEOs and Public Pension Funds on the Corporate Governance Issues of Chairman-CEO Duality and the Election of Lead Directors', American Business Review, January, pp. 49-54.

Backman, M 2004, The Asian Insider: Unconventional wisdom for Asian Business, Palgrave macmillan, London.

Backman, M 2001, Asian Eclipse: Exposing the Dark Side of Business in Asia, John Wiley \& Sons (Asia), Singapore.

Backman, M and Butler, C 2003, Big in Asia: 25 strategies for business success, Palgrave macmillan, London.

Bradley, N 2004, 'Corporate Governance Scoring and the Link Between Corporate Governance and Performance Indicators: in search of the Holy Grail', Corporate Governance, vol. 12, no. 1, pp. 810.

Brickley, JA, Coles, JL \& Jarrell, G 1997, 'Leadership structure: Separating the CEO and Chairman of the Board', Journal of Corporate Finance, vol. 3, pp. 189-220.

Buchanan, B \& Yang, T 2005, 'The benefits and costs of controlling shareholders: the rise and fall of Parmalat', Research in International Business and Finance, vol. 19, pp. 27-52.

Chan, HC 2003, 'Economic Briefing to the Penang State Government', Socio-Economic \& Environmental Research Institute, vol. 5, no. 8, pp. 1-3.

Chang, AAL 2004, 'The Impact of Corporate Governance Practices on Firms' Financial Performance: Evidence from Malaysian Companies', ASEAN Economic Bulletin, vol. 21, no. 3, pp. 308-318.

Claessens, S, Djankov, S \& Lang, LHP 2000, 'The Separation of Ownership and Control in East Asian Corporations', Journal of Financial Economics, vol. 58, pp. 81-112.

Clarke, T 2004, 'Cycle of Crisis and Regulation: the enduring agency and stewardship problems of corporate governance', Corporate Governance, vol. 12, no. 2, pp. 153-161.

Coles, JW \& Hesterly, WS 2000, 'Independence of the Chairman and Board Composition: Company Choices and Shareholder Value', Journal of Management, vol. 26, no. 2, 195-214.

Coles, JW, McWilliams, VB \& Sen, N 2001, 'An examination of the relationship of governance mechanisms to performance', Journal of Management, vol. 27, pp. 23-50.

Coulson-Thomas, C 2005, 'Creating a winning board', Strategic Direction, vol. 21, no. 3, pp. 3-5. 
Crookes, D \& Thomas, I 1998, 'Problem solving and culture - exploring some stereotypes', Journal of Management Development, vol. 17, no. 8, pp. 583-591.

Dahya, J \& Travlos, NG 2000, 'Does the one man show pay? Theory and evidence on the dual CEO revisited', European Financial Management, vol. 6, no. 1, pp. 85-98.

Daily, CM \& Dalton, DR 1997, 'Separate, But Not Independent: board leadership structure in large corporations', Corporate Governance, vol. 5, no. 3, 126-136.

Daily, CM, Dalton, DR \& Cannella, AA 2003, 'Corporate Governance: Decades of Dialogue and Data', Academy of Management Review, vol. 28, no. 3, pp. 371-382.

Daily, CM, McDougall, PP, Covin, JG \& Dalton, DR 2002, 'Governance and Strategic Leadership in Entrepreneurial Companies', Journal of Management, vol. 28, no. 3, pp. 387-412.

Elloumi, F \& Gueyie, JP 2001, 'Financial Distress and Corporate Governance: an empirical analysis', Corporate Governance, vol. 1, no. 1, pp. 15-23.

Fan, DKK, Lau, CM \& Wu, S 2002, 'Corporate Governance Mechanisms', The Chinese University of Hong Kong Discussion Paper, pp. 211-240.

Finkelstein, S \& D'Aveni, RA 1994, 'CEO Duality as a double-edged sword: How boards of directors balance entrenchment avoidance and unity of command', Academy of Management Journal, vol. 37, no. 5, pp. 1079-1108.

Finkelstein, S \& Mooney, AC 2003, 'Not the usual suspects: How to use board process to make boards better', Academy of Management Executive, vol. 17, no. 2, pp. 101-113.

Fosberg, RH \& Nelson, MR 1999, 'Leadership structure and firm performance', International Review of Financial Analysis, vol. 8, no. 1, pp. 83-96.

Gunther, M 2002, 'The Directors: Disney Boardroom Drama', Fortune, vol. 146, no. 6, pp. 90-94.

Haat, MHC \& Mahenthiran, S 2003, 'Is Corporate Governance an issue in PN4 Companies?' in International Conference on "Quality Financial Reporting and Corporate Governance-Building Public Trust, Integrity and Accountability”, Kuala Lumpur, Malaysia, pp. 1-30.

Haley, GT 1997, 'A strategic perspective on overseas Chinese networks' decision making', Management Decision, vol. 35, no. 8, pp. 587-594.

Haley, GT \& Tan, CT 1999, 'East vs. West: strategic marketing management meets the Asian networks', Journal of Business \& Industrial Marketing, vol. 14, no. 2, pp. 91-101.

Haley, UCV 2000, 'Corporate Governance and Restructuring in East Asia: An Overview' in $8^{\text {th }}$ SJE Conference on Corporate Governance and Restructuring in East Asia, Seoul, South Korea, pp. 152.

Haniffa, RM \& Cooke, TE 2002, 'Culture, Corporate Governance and Disclosure in Malaysian Corporations' Abacus, vol. 38, no. 13, pp. 317-349.

Hutchings, K \& Murray, G 2002, 'Working with Guanxi: An Assessment of the Implications of Globalisation on Business Networking in China', Creativity and Innovation Management, vol. 11, no. 3, pp. 184-191.

Jones, I \& Pollitt, M 2004, 'Understanding How Issues in Corporate Governance Develop: Cadbury Report to Higgs Review', Corporate Governance, vol. 12, no. 2, pp. 162-171.

Kadir, AA 1999, 'The Corporate Governance Trends in Malaysia: February 1999 Finance Committee Report on Corporate Governance' in Corporate Governance Conference for Nominee Directors of $P N B$, Kuala Lumpur, pp. 1-12.

Kang, SM 2001, The Listing Requirements of Kuala Lumpur Stock Exchange: What Directors and Senior Management Need to Know, Butterworths Asia, Singapore.

Keenan, J 2004, 'Corporate Governance in UK/USA Boardrooms', Corporate Governance, vol. 12, no. 2, pp. 172-176.

Khan, HA 1998, 'Corporate Governance of Family Businesses in Asia: What's Right and What's Wrong?', World Bank Working Paper, pp. 1-41.

Khan, HA 2003, 'Corporate Governance: The Limits of the Principal-Agent Approach in Light of the Family-Based Corporate Governance System in Asia', CIRJE Discussion Paper, pp. 1-65.

Khatri, Y, Leruth, L \& Piesse, J 2003, 'Corporate Performance and Governance: A Stochastic Frontier Approach to Measuring and Explaining Inefficiency in the Malaysian Corporate Sector', International Monetary Fund Working Paper, pp. 1-26. 
Kiel, GC \& Nicholson, GJ 2003, 'Board Composition and Corporate Performance: how the Australian experience informs contrasting theories of corporate governance', Corporate Governance, vol. 11, no. 3, pp 189-205.

Kim, D, Kandemir, D \& Cavusgil, ST 2004, 'The Role of Family Conglomerates in Emerging Markets: What Western Companies Should Know', Thunderbird International Business Review, vol. 46, no. 1, pp. 13-38.

Kirkbride, J \& Letza, S 2004, 'Regulation, Governance and Regulatory Collibration: achieving an "holistic" approach', Corporate Governance, vol. 12, no. 1, pp 85-92.

KLSE-PricewaterhouseCoopers 2002, Corporate Governance: Malaysian Survey of Public Listed Companies, Independent Non-Executive Directors and Institutional Groups.

Kotler, P and Kartajaya, H 2000, Repositioning Asia: From Bubble to Sustainable Economy, John Wiley \& Sons (Asia) Pte Ltd, Singapore.

Letza, S, Sun, X \& Kirkbride, J 2004, 'Shareholding Versus Stakeholding: a critical view of corporate governance', Corporate Governance, vol. 12, no. 3, pp. 242-262.

Li, J, Khatri, N \& Lam, K 1999, 'Changing strategic postures of overseas Chinese companies in emerging Asian markets', Management Decision, vol. 37, no. 5, pp. 445-456.

Li, J \& Wright, PC 2000, 'Guanxi and the realities of career development: a Chinese perspective', Career Development International, vol. 5, no. 7, pp. 369-378.

Low, CK 2003, 'A road map for Corporate Governance in East Asia', The Chinese University of Hong Kong.

Low, KLT, Yong, DGF, \& Shanmugam, B 2004, 'The enigma of Corporate Governance', Corporate Ownership \& Control, vol. 1, no. 3, pp. 13-19.

$\mathrm{Lu}, \mathrm{J} \&$ Batten, J 2001, 'The Implementation of OECD Corporate Governance Principles on Post-Crisis Asia', JCC, vol. 4, pp. 47-62.

Lyngaas, J 2002, 'Corporate Governance: Will Asia Buy It?', Spotlight on Business, pp. 10-16.

Mak, YT \& Li, Y 2001, 'Determinants of corporate ownership and board structure: evidence from Singapore', Journal of Corporate Finance, vol. 7, pp. 235-256.

Mitton, T 2002, 'A cross-company analysis of the impact of corporate governance on the East Asian financial crisis', Journal of Financial Economics, vol. 64, pp. 215-241.

Navaratnam, RV 2003, Malaysia's Economic Challenge: A Critical Analysis of the Malaysian Economy, Governance and Society, Asian Academic Press, London.

Nicholson, GJ \& Kiel, GC 2004, 'Breakthrough board performance: how to harness your board's intellectual capital[1]', Corporate Governance, vol. 4, no. 1, pp. 5-23.

Osman, YA 2004, 'Protecting minority shareholders: Issues and Challenges' in International Conference on Corporate Governance \& Reporting, Kuala Lumpur, Malaysia, pp. 1-24.

Ow-Yong, K \& Cheah, KG 2000, 'Corporate Governance Codes: a comparison between Malaysia and the UK', Corporate Governance, vol. 8, no. 2, pp. 125-132.

Rahman, RA \& Haniffa, RM 2005, 'The effect of role duality on corporate performance in Malaysia', Corporate Ownership \& Control, vol. 2, no. 2, pp. 40-47.

Roberts, J 2002, 'Building the Complementary Board. The Work of the Plc Chairman', Long Range Planning, vol. 35, pp. 493-520.

Salleh, SM 2004, Opening Address on 'Financial Reporting and Alternative Solutions to Achieving Better Corporate Governance' in Corporate Governance Conference, Kuala Lumpur.

Simpson, WG \& Gleason, AE 1999, 'Board Structure, ownership, and financial distress in banking companies', International Review of Economics and Finance, vol. 8, pp. 281-292.

Soederberg, S 2003, 'The promotion of 'Anglo-American' corporate governance in the South: who benefits from the new international standard?', Third World Quarterly, vol. 24, no. 1, pp. 7-27.

Sonnenfeld, J 2004, 'Good governance and the misleading myths of bad metrics', Academy of Management Executive, vol. 18, no. 1, pp. 108-113.

Steier, LP, Chrisman, JJ \& Chua, JH 2004, 'Entrepreneurial Management and Governance in Family Companies: An Introduction', Entrepreneurship Theory and Practice, summer, pp. 295-303.

Sundaramurthy, C, Mahoney, JM \& Mahoney, JT 1997, 'Board structure, antitakeover provisions, and stockholder wealth', Strategic Management Journal, vol. 18, no. 3, pp. 231-245. 
The Borneo Post 6 February 2004, 'SC will act against errant directors, CEOs', p. B12.

The Borneo Post 29 July 2003, 'Partners in development, p. 1.

The Borneo Post 28 Nov 2002, 'Genting casino Lim resigns after 34 years', p. 1.

The Business Times 5-6 March 2005, 'Tackling corporate problems', p. 7.

Tong, CK \& Yong, PK 1998, 'Guanxi bases, Xinyong and Chinese business networks', Brit. Jnl. of Sociology, vol. 49, no. 1, pp. 75-96.

Vafeas, N \& Theodorou, E 1998, 'The relationship between board structure and firm performance in the UK', British Accounting Review, vol. 30, pp. 383-407.

Walker, G \& Fox, M 2002, 'Corporate governance reform in East Asia', Corporate Governance, vol. 2, no. 1, pp. 4-9.

Ward, S, Pearson, C \& Entrekin, L 2002, 'Chinese cultural values and the Asian meltdown', International Journal of Social Economics, vol. 29, no. 3, pp. 205-217.

Weir, C 1997, 'Acquisitions and company characteristics: the importance of internal monitoring mechanisms', Management Decision, vol. 35, no. 2, pp. 155-162.

Weir, C \& Laing, D 2001, 'Governance structures, director independence and corporate performance in the UK', European Business Review, vol. 13, no. 2, pp. 86-94.

Wilson, I 2004, 'The agenda for redefining corporate purpose: five key executive actions', Strategy \& Leadership, vol. 32, no. 1, pp. 21-26.

$\mathrm{Wu}, \mathrm{YL} 2004$, 'The impact of public opinion on board structure changes, director career progression, and CEO turnover: evidence from CalPER's corporate governance program', Journal of Corporate Finance, vol. 10, pp. 199-227.

Yeh, YH, Lee, TS \& Woidtke, T 2001, 'Family Control and Corporate Governance: Evidence from Taiwan', International Review of Finance, vol. 2, no. 1/2, pp. 21-48.

Yeung, HWC 1999, 'Under siege? Economic globalization and Chinese business in Southeast Asia', Economy and Society, vol. 28, no. 1, pp. 1-29.

Yeung, HWC \& Soh, TM 2000, 'Corporate Governance and the Global Reach of Chinese Family Companies in Singapore' in Conference on 'Corporate Governance and Restructuring in East Asia', South Korea, pp. 1-42.

Yu, TFL 2001, 'The Chinese family business as a strategic system: an evolutionary perspective', International Journal of Entrepreneurial Behaviour \& Research, vol. 7, no. 1, pp. 22-40.

Zong, L 2004, 'The Road To Stronger Corporate Governance', The Corporate Board, March/April, pp. 16-21. 
